\title{
Nilai-nilai Pendidikan Islam dalam Maulid Nabi Muhammad SAW
}

\section{Musohihul Hasan,M.Pd.I Abstraksi}

Maulid Nabi Muhammad SAW kadang-kadang Maulid Nabi atau Maulud saja (bahasa Arab: مولـد النبي , mawlid annabì), adalah peringatan hari lahir Nabi Muhammad SAW, yang di Indonesia perayaannya jatuh pada setiap tanggal 12 Rabiul Awal dalam penanggalan Hijriyah. Perayaan Maulid Nabi merupakan tradisi yang berkembang di masyarakat Islam jauh setelah Nabi Muhammad SAW wafat. Secara subtansi, peringatan ini adalah ekspresi kegembiraan dan penghormatan kepada Rasulullah Muhammad SAW dengan berbagai bentuk kegiatan seperti pembacaan shalawat nabi, syair barzanji, dll sebagai upaya untuk mengenal akan keteladanan Nabi sebagai pembawa ajaran agama islam, namun terkadang terdapat beberapa golongan yang berpendapat jika perayaan mauled Nabi dikatkan bid'ah dan didalamnya tidak terkandung nilai - nilai yang bisa di ambil, termasuk pendidikan. Bertitik tolak dari uaraian di atasa, maka penulis termotifasi untuk mengkaji dan menganalisa lebih jauh tentang "studi analisis Nila-nilai Pendidikan Islam dalam Maulid Nabi Muhammad SAW".

Kata kunci: Nila-nilai Pendidikan Islam, Peringatan Maulid Nabi Muhammad 


\section{A. Kajian Tentang Nilai}

\section{Pengertian Nilai.}

Nilai (value) berasal dari bahasa latin valare atau bahasa prancis kuno valoir yang artinya nilai. Sebatas arti denotatifnya, valare, valoir, value, dan nilai dapat dimaknai sebagai harga ${ }^{1}$. Hal ini selaras dengan definisi nilai dalam kamus besar Bahasa Indonesia karangan departemen pendidikan nasional yang diartikan dengan harga, harga rupiah, angka kepandaian, banyak sedikitnya isi; kadar mutu, sifat-sifat (hal-hal) yang penting atau berguna bagi kemanusiaan dan sesuatu yang menyempurnakan manusia sesuai dengan hakikatnya ${ }^{2}$

Dalam arti lain, nilai adalah konsepsi-konsepsi abstrak dalam diri manusia atau masyarakat, mengenai hal-hal yang dianggap baik, benar dan hal-hal yang dianggap buruk dan salah. ${ }^{3}$

Muhaimin dan Abdul Mujib mendefinisikan nilai sebagai sesuatu yang praktis dan efektis dalam jiwa dan tindakan manusia serta melembaga secara obyektif di dalam masyarakat. ${ }^{4}$

$\mathrm{H}$ Titus, M. S, et. al. mengartikannya kualitas yang membangkitkan respon penghargaan ${ }^{5}$. Jadi, berdasarkan pada definisi diatas dapat disimpulkan bahwa nilai adalah sesuatu yang berharga dan berguna yang bermanfaat bagi manusia serta diugemi sebagai acuan tingkah laku.

1 Tim Pengembang IImu Pendidikan, 2009, Ilmu dan Aplikasi Pendidikan Bagian III, PT. Imtima, Bandung, hlm. 42.

2 Departemen Pendidikan Nasional (2011), Kamus besar Bahasa Indonesia Pusat

Bahasa, hlm. 963

3 HMI Cab. Bogor. (1989). Nilai-Nilai Identitas Kader NIK. Buku Pedoman HMI Cab. Bobor. HIm. 79.

4 Muhaimin dan Abdul Mujib, 1993, Pemikiran Pendidikan Islam, Tri Genda Karya, Bandung, hlm. 110

5 H Titus, M. S, et. al, 1984, Persoalan-Persoalan Filsafat, Bulan Bintang, Jakarta. hlm. 122. 


\section{Hirarki Nilai (Tingkatan Nilai)}

Hirarki nilai sangat tergantung dari sudut pandang dan nilai yang menjadi patokan dasar si penilai. Tingkatan atau hirarki nilai akan berbeda antara orang atheis dengan orang religius, demikian juga dengan orang materialis. Bagi orang religius tentu saja nilainilai religi akan menempati posisi utama atau tertinggi, sementara bagi orang materialis akan menempatkan nilai materi pada posisi tertinggi. Nilai tentu saja di pandang penting oleh setiap orang. Namun tingkat kepentingan nilai tersebut tidaklah sama, itulah sebabnya nilai memiliki tingkatan, dalam pengertian ada hirarkinya.

Max Scheller menyebutkan hirarki nilai terdiri dari :

a. Nilai Kenikmatan, yaitu nilai yang mengenakkan atau tidak mengenakkan, yang berkaitan dengan indra manusia yang menyebabkan manusia senang atau menderita.

b. Nilai kehidupan, yaitu nilai yang penting bagi kehidupan.

c. Nilai kejiwaan, yaitu nilai yang tidak tergantungpada keadaan jasmani maupun lingkungan.

d. Nilai kerohanian, yaitu moralitas nilai dari yang suci dan tidak suci. ${ }^{6}$

\section{Nilai-Nilai dalam Islam}

Nilai-nilai dalam islam mengandung dua kategori arti dilihat dari segi normative, yaitu baik dan buruk, hak dan batil, benar dan salah, diridhai dan dikutuk oleh Allah SWT. Sedang dilihat dari segi

6 Tim Pengembang Ilmu Pendidikan, 2007, Op. Cit., hlm. 52 
operatif nilai tersebut mengandung lima pengertian kategori yang menjadi prinsip standardisasi prilaku manusia, yaitu sebagai berikut:

a. Wajib atau fardhu, yaitu bila dikerjakan orang akan mendapat pahala dan bila ditinggalkan orang akan mendapat siksa Allah SWT

b. Sunnah atau mustahab, yaitu bila dikerjakan orang akan mendapat pahala dan bila ditinggalkan orang tidak akan disiksa

c. Mubah atau jaiz, yaitu bila dikerjakan orang tidak akan disiksa dan tidak diberi pahala serta bila ditinggalkan tidak pula disiksa oleh Allah SWT dan dan juga tidak diberi pahala

d. Makruh, yaitu bila dikerjakan orang tidak disiksa, hanya tidak disukai oleh Allah SWT dan bila ditinggalkan, orang akan mendapatkan pahala.

e. Haram, yaitu bila dikerjakan orang mendapat siksa dan bila di tinggalkan orang akan memperoleh pahala.

Kelima nilai kategorial yang operatif di atas berlaku dalam situasi dan kondisi biasa. Dan bila manusia dalam situasi kondisi darurat (terpaksa), pemberlakuan nilai-nilai tersebut bias berubah. Sebagai contoh pada waktu orang dalam situasi dan kondisi kelaparan karena tidak ada makanan yang halal, maka orang diperbolehkan memakan makanan yang dalam keadaan biasa hukumnya haram, seperti daging babi, anjing, bangkai, dan sebagainya. ${ }^{7}$

Dalam pandangan Islam, tidak semua nilai yang telah melembaga dalam suatu tata kehidupan masyarakat, diterima atau ditolak. Sikap

7 H. Muzayyin Arifin, M.Ed, Op. Cit., hlm. 127 
Islam dalam menghadapi tata nilai masyarakat adalah menggunakan lima macam klasifikasi, yaitu:

A. Memelihara unsur-unsur nilai dan norma yang sudah mapan dan positif.

B. Menghilangkan unsur-unsur nilai dan norma yang sudah mapan tetapi negatif.

C. Menumbuhkan unsur-unsur nilai dan norma baru yang belum ada dan dianggap positif.

D. Bersikap menerima (receptive), memilih (selective), mencerca (digestive), menggabung-gabungkan dalam satu sistem (assimilative), dan menyampaikan pada orang lain (transmissive) terhadap nilai pada umumnya.

E. Menyelenggarakan pengkudusan atau penyucian nilai atau norma agar sesuai dan sejalan dengan nilai-nilai dan normanorma Islam sendiri. Tegasnya adalah menyelenggarakan Islamisasi nilai dan norma. Sehingga akan terwujud hubungan yang ideal antara nilai agama Islam dan nilai sekelompok masyarakat, yaitu terbinanya nilai masyarakat yang dijiwai dan ditopang oleh nilai-nilai abadi dan universal yang terdapat pada wahyu Ilahi. ${ }^{8}$

\section{Pengertian Nilai-nilai Pendidikan Islam}

Menurut Ali Sarwan, nilai pendidikan Islam adalah ciri-ciri atau sifat khas Islami yang dimiliki sistem pendidikan Islam. ${ }^{9}$ Rajab Dauri mengatakan nilai-nilai pendidikan Islam adalah corak atau sifat yang melekat pada pendidikan Islam. $^{10}$ Sedangkan Ruqaiyah $\mathrm{M}$.

8 Endang Saifuddin (1982), Agama Dan Kebudayaan, Bina Ilmu, Surabaya, hlm. 73.

9 Ali Sarwan, Ciri-ciri Pendidikan Islam,(Internet, 23 Maret 2006), h. 5

10 Rajab dauri, Islam dan Nilai, (Internet, 17 Juli 2007), h. 4 
berpendapat nilai-nilai pendidikan Islam adalah ada pada determinasi yang terdiri dari cara pandang, aturan dan norma yang ada pada pendidikan Islam yang selalu berkaitan dengan akidah, ibadah, syariah, dan akhlak. ${ }^{11}$ Dengan demikian dapat dipahami bahwa nilainilai pendidikan Islam adalah ciri khas, sifat yang melekat yang terdiri dari aturan dan cara pandang yang dianut oleh agam Islam.

\section{Dasar-Dasar Pendidikan Islam}

Dasar ilmu pendidikan Islam adalah dengan segala ajarannya. Ajaran itu bersumber pada Alquran, sunnah Rasulullah SAW, ijma', qiyas, dan ra'yu (hasil pikiran manusia).

\section{a. Al Quran}

Al-Quran adalah Kalam Allah SWT. yang diturunkan kepada nabi Muhammad SAW dalam bahasa Arab yang terang guna menjelaskan jalan hidup yang bermaslahat bagi umat manusia di dunia dan di akhirat. Selanjutnya Alquran juga memerankan fungsi sebagai pengontrol dan pengoreksi terhadap perjalanan hidup manusia dimasa lalu.

\section{b. Al-Sunnah}

Sunnah menurut jumhurul Ulama atau kebanyakan para ulama hadits mengartikan Al-Sunnah, Al-Hadits, Al-Khabar dan Al-Atsar sama saja, yaitu segala sesuatu yang disandarkan kepada Nabi Muhammad SAW baik dalam bentuk ucapan, perbuatan maupun ketetapan ${ }^{12}$.

\section{c. Al Ijma'}

Ijma' dalam arti bahasa ialah: permufakatan, namun dalam istilahnya ulama ahli usulul fiqh ialah: permufakatan para mujtahid

11 Ruqaiyah M, Konsep Nilai dalam Pendidikan Islam, (Padangsidimpuan: Makalah STAIN Padangsidimpuan, 2006), h. 12

12 Hery Noer Aly (1999), Ilmu Pendidikan Islam (Cet. 1), PT. Logos, Jakarta, hlm. 30. 
di dalam menetapkan hukum dalam suatu zaman wafatnya nabi Muhammad SAW ${ }^{13}$.

\section{d. Al Qiyas}

Qiyas adalah menyamakan hukum furu' kepada hukum yang berlaku dalam asal sebab suatu illat yang terkandung dalam keduanya (furu' dan asal) yang mengkibatkan bisa terkumpulnya kedua-duanya dalam satu hukum, seperti mengiaskan memukul orang tua (furu') kepada kata 'uuf' (asal) di dalam hukum haram, sebab sama di dalam illatnya ialah menyakiti. ${ }^{14}$

\section{e. $R a^{\prime} y u$}

Ijtihad pada dasarnya merupakan usaha sungguh-sungguh orang muslim untuk selalu berperilaku berdasarkan ajaran Islam. Untuk itu, manakala tidak ditemukan petunjuk yang jelas dari AlQuran ataupun Sunnah tentang suatu perilaku, orang muslim akan mengerahkan segenap kemampuannya untuk menemukannya dengan memperhatikan prinsip-prinsip umum Al-Quran ataupun Sunnah.

\section{Strategi Pendidikan Islam}

Strategi pendididkan pada hakikatnya adalah pengetahuan atau seni mendayagunakan semua faktor/kekuatan untuk mengamankan sasaran pendidikan yang hendak dicapai melalui perencanaan dan pengarahan dalam operasionalisasi sesuai dengan situasi dan kondisi yang ada. Strategi pendidikan dapat juga diartikan sebagai kebajikan dan metode umum pelaksanaan proses pendidikan. Seperti yang ditujukan Allah dalam firmannya antara lain:

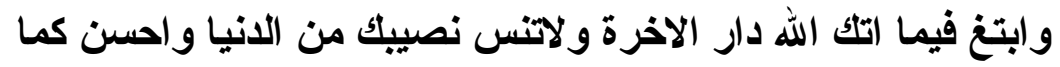

13 Ibid.,

14 H. A. Djauhari Aris, Miftahul Ushul, Al-lkhsan, Surabaya, hlm. 62. 


\section{(حسن الله اليك..(القصص:CV)}

Artinya: Dan berusahalah mendapatkan segala apa yang telah Allah berikan mengenai tempat tinggalmu di akhitrat, dan janganlah kamu melupakan nasib hidupmu di dunia, dan berbuatlah kebaiakan sebaimana Allah telah berbuat kebaikan kepadamu.'(QS.Al Mujadalah: 77).

\section{Tujuan Pendidikan Islam}

Tujuan adalah batas akhir yang dicita-citakan seseorang dan dijadikan pusat perhatiannya untuk dicapai melalui usaha., yang di dalamnya terkandung cita-cita, kehendak, dan kesengajaan, serta berkonsekuensi penyusunan daya upaya untuk mencapainya.

Tujuan pendidikan dapat dilihat dari berbagai segi. Dilihat dari segi gradasinya ada dua bentuk yaitu:

\section{a. Tujuan Akhir}

Tujuan ini disebut juga tujuan tertinggi, tujuan umum, tujuan total, dan tujuan lengkap. Dalam tujuan ini para ahli memberikan pengertian yang berbeda, seperti:

1) Imam al Ghazali berpendapat; tujuan akhir pendidikan Islam adalah kesempurnaan insani di dunia dan akhirat.

2) Muhammad Athiyyah al Abrasyi menyatakan; tujuan akhir pendidikan Islam adalah tercapainya akhlak yang sempurna atau keutamaan.

3) Menurut Ahmad D marimaba tujuan akhir pendidikan adalah terbentuknya kepribadian muslim ${ }^{15}$.

b. Tujuan Sementara

15 Hery Noer Aly (1999), Ilmu Pendidikan Islam (Cet. 1), hlm. 76. 
Tujuan sementara merupakan penjabaran dari tujuan akhir serta berfungsi membantu memelihara arah seluruh usaha dan menjadi batu loncatan untuk mencapai tujuan akhir.

Menurut Al-Syaibani, tujuan pendidikan Islam di bagi menjadi tiga yaitu :

1) Tujuan yang berkaitan dengan individu, mencakup perubahan yang berupa pengetahuan, tingkah laku masyarakat, tingkah laku jasmani dan rohani dan kemampuan-kemampuan yang harus dimiliki untuk hidup di dunia dan di akhirat.

2) Tujuan yang berkaitan dengan masyarakat, mencakup tingkah laku masyarakat, tingkah laku individu dalam masyarakat, perubahan kehidupan masyarakat, memperkaya pengalaman masyarakat.

3) Tujuan profesional yang berkaitan dengan pendidikan dan pengajaran sebagai ilmu, sebagai seni, sebagai profesi, dan sebagai kegiatan masyarakat ${ }^{16}$.

\section{B. Kajian Tentang Pendidikan Islam}

\section{Pengertian Pendidikan Islam}

Para ahli juga memberikan definisi pendidikan Islam secara langsung, diantaranya seperi dibawah ini:

1) Prof. Dr. Omar Muhammad Al-Toumy Al Syaebani mengartikan pendidiakn Islam sebagai usaha untuk mengubah tingkah laku individu dalam kehidupan pribadinya atau kehidupan kemasyarakatannya dan kehidupan dalam alam sekitarnya melalui proses kependidikan ${ }^{17}$.

16 Omar Muhammad Al-Toumy Al-Syaibany, Falsafatut Tarbiyah Islamiyah, hlm. 478.

17 Omar Muhammad Al-Toumy Al-Syaibany, Falsafatut Tarbiyah Islamiyah, (terj. Hasan Langgulung), Bulan Bintang, Jakarta, hlm. 57. 
2) Dr. Muhammad Fadil Al-Djamaly, Pendidikan Islam adalah proses yang mengarahkan manusia kepada kehidupan yang baik dan yang mengangkat derajat kemanusiaannya sesuai dengan kemampuan dasar (fitrah) dan kemampuan ajarnya (pengaruh dari luar).

3) Menurut M. Yusuf al Qardhawi adalah pendidikan manusia seutuhnya, akal dan hatinya, rohani dan jasmaninya, akhlak dan ketrampilannya. Karenanya pendidikan Islam berupaya menyiapkan manusia untuk hidup baik dalam keadaan damai maupun perang, dan menyiapkannya untuk menghadapi masyarakat dengan segala kebaikan dan kejahatannya, manis dan pahitnya ${ }^{18}$.

4) Hasan Langgulung merumuskan pendidikan Islam sebagai suatu proses penyiapan generasi muda untuk mengisi peranan, memindahkan kemampuan pengetahuan dan nilainilai Islam yang diselaraskan dengan fungsi manusia untuk beramal dan memetik hasilnya kelak di akhirat. ${ }^{19}$

\section{Dasar-Dasar Pendidikan Islam}

Dasar ilmu pendidikan Islam adalah dengan segala ajarannya. Ajaran itu bersumber pada Alquran, sunnah Rasulullah SAW, ijma', qiyas, dan ra'yu (hasil pikiran manusia).

\section{A. Al Quran}

Al-Quran adalah Kalam Allah SWT. yang diturunkan kepada nabi Muhammad SAW dalam bahasa Arab yang terang guna menjelaskan jalan hidup yang bermaslahat bagi umat manusia di dunia dan di akhirat. Selanjutnya Alquran juga memerankan fungsi sebagai pengontrol dan pengoreksi terhadap perjalanan hidup manusia dimasa lalu.

18 Yusuf al Qardhawi (1980), Pendidikan Islam dan Madrasah Hasan Al-Banna, (terj. Bustami A, Gani et.al), Bulan Bintang, Jakarta, hlm. 157.

19 Hasan Langgulung (1980), Beberapa Pemikiran tentang Pendidikan Islam, AlMa’arif, Bandung, hlm. 6. 


\section{B. Al-Sunnah}

Sunnah menurut jumhurul Ulama atau kebanyakan para ulama hadits mengartikan Al-Sunnah, Al-Hadits, Al-Khabar dan Al-Atsar sama saja, yaitu segala sesuatu yang disandarkan kepada Nabi Muhammad SAW baik dalam bentuk ucapan, perbuatan maupun ketetapan ${ }^{20}$.

Sebagai sumber ajaran Islam yang kedua, setelah AlQuran, Al-Sunnah memiliki fungsi yang pada intinya sejalan dengan AlQuran. Keberadaan Al-Sunnah tidak dapat dilepaskan dari adanya sebagian ayat Al-Quran:

1). Yang bersifat global (garis besar) yang memerlukan perincian;

2). Yang bersifat umum (menyeluruh) yang menghendaki pengecualian;

3). Yang ebrsifat mutlak (tanpa batas) yang menghendaki pembatasan; dan,

4). Isyarat Al-Quran yang mengandung makna lebih dari satu (musytarak) yang menghendaki penetapan makna yang akan dipakai dari dua makna tersebut; bahkan terdapat sesuatu yang secara khusus tidak dijumpai keterangannya di dalam Al-Quran yang selanjutnya diserahkan kepada hadis nabi ${ }^{21}$.

\section{2) Al Ijma'}

Ijma' dalam arti bahasa ialah: permufakatan, namun dalam istilahnya ulama ahli usulul fiqh ialah: permufakatan para mujtahid di dalam menetapkan hukum dalam suatu zaman wafatnya nabi Muhammad SAW ${ }^{22}$.

20 Hery Noer Aly (1999), Ilmu Pendidikan Islam (Cet. 1), PT. Logos, Jakarta, hlm. 30.

21 H. Abuddin Nata (2004), Metodologi Studi Islam (Cet. 9), PT. Raja Grafindo Persada, Jakarta, hlm. 75

22 Ibid., 185

H. A. Djauhari Aris, Miftahul Ushul, Al-Ikhsan, Surabaya, hlm. 62. 


\section{3) Al Qiyas}

Qiyas adalah menyamakan hukum furu' kepada hukum yang berlaku dalam asal sebab suatu illat yang terkandung dalam keduanya (furu' dan asal) yang mengkibatkan bisa terkumpulnya kedua-duanya dalam satu hukum, seperti mengiaskan memukul orang tua (furu') kepada kata 'uuf' ' (asal) di dalam hukum haram, sebab sama di dalam illatnya ialah menyakiti. ${ }^{185}$

\section{4) $R a^{\prime} y u$}

Ijtihad pada dasarnya merupakan usaha sungguh-sungguh orang muslim untuk selalu berperilaku berdasarkan ajaran Islam. Untuk itu, manakala tidak ditemukan petunjuk yang jelas dari AlQuran ataupun Sunnah tentang suatu perilaku, orang muslim akan mengerahkan segenap kemampuannya untuk menemukannya dengan memperhatikan prinsip-prinsip umum Al-Quran ataupun Sunnah.

Ijtihad dalam lapangan pendidikan perlu mengimbangi ijtihad dalam lapangan fiqih (lahir dan batinnya), menginat yang pertama merupakan usaha pembudayaannya, sedangkan yang kedua merupakan penggalian isi budaya itu. ${ }^{23}$

\section{Tugas dan Fungsi Pendididkan Islam}

Berdasarkan pernyataan John Dewey "Education is the process without end" (pendidikan) "pendidikan itu adalah suatu proses tempat akhir." Pendidikan Islam memiliki tugas dan fungsi yang berlangsung secara kontinu yang bersasaran pada manusia, diantarnya sebagai berikut:

23 Hery Noer Aly (1999), Ilmu Pendidikan Islam (Cet. 1), hlm. 49. 
a. Membimbing dan mengarahkan pertumbuhan dan perkembangan kehidupan anak didik dari satu tahap ke tahap yang lain sampai mencapai kemampuan yang optimal.

b. Menyediakan fasilitas yang di dalamnya mengandung arti dan tujuan yang bersifat structural dan konstitusional, dan dapat memungkinkan tugas pendidikan tersebut dapat berjalan lancar.

\section{Strategi Pendidikan Islam}

Strategi pendididkan pada hakikatnya adalah pengetahuan atau seni mendayagunakan semua faktor/kekuatan untuk mengamankan sasaran pendidikan yang hendak dicapai melalui perencanaan dan pengarahan dalam operasionalisasi sesuai dengan situasi dan kondisi yang ada. Strategi pendidikan dapat juga diartikan sebagai kebajikan dan metode umum pelaksanaan proses pendidikan. Seperti yang ditujukan Allah dalam firmannya antara lain:
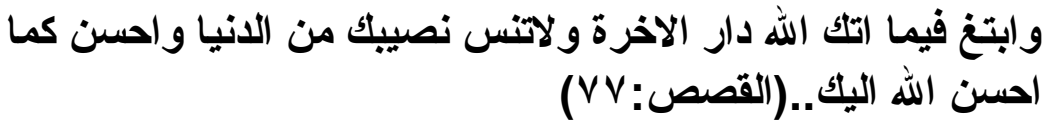

Artinya: Dan berusahalah mendapatkan segala apa yang telah Allah berikan mengenai tempat tinggalmu di akhitrat, dan janganlah kamu melupakan nasib hidupmu di dunia, dan berbuatlah kebaiakan sebaimana Allah telah berbuat kebaikan kepadamu.'(QS.Al Mujadalah: 77).

\section{Tujuan Pendidikan Islam}

Tujuan adalah batas akhir yang dicita-citakan seseorang dan dijadikan pusat perhatiannya untuk dicapai melalui usaha., yang di 
dalamnya terkandung cita-cita, kehendak, dan kesengajaan, serta berkonsekuensi penyusunan daya upaya untuk mencapainya.

Tujuan pendidikan dapat dilihat dari berbagai segi. Dilihat dari segi gradasinya ada dua bentuk yaitu:

\section{A. Tujuan Akhir}

Tujuan ini disebut juga tujuan tertinggi, tujuan umum, tujuan total, dan tujuan lengkap. Dalam tujuan ini para ahli memberikan pengertian yang berbeda, seperti:

a. Imam al Ghazali berpendapat; tujuan akhir pendidikan Islam adalah kesempurnaan insani di dunia dan akhirat.

b. Muhammad Athiyyah al Abrasyi menyatakan; tujuan akhir pendidikan Islam adalah tercapainya akhlak yang sempurna atau keutamaan.

c. Menurut Ahmad D marimaba tujuan akhir pendidikan adalah terbentuknya kepribadian muslim ${ }^{24}$.

\section{B. Tujuan Sementara}

Tujuan sementara merupakan penjabaran dari tujuan akhir serta berfungsi membantu memelihara arah seluruh usaha dan menjadi batu loncatan untuk mencapai tujuan akhir. Menurut Al-Syaibani, tujuan pendidikan Islam di bagi menjadi tiga yaitu

a. Tujuan yang berkaitan dengan individu, mencakup perubahan yang berupa pengetahuan, tingkah laku masyarakat, tingkah laku jasmani dan rohani dan kemampuan-kemampuan yang harus dimiliki untuk hidup di dunia dan di akhirat.

b. Tujuan yang berkaitan dengan masyarakat, mencakup tingkah laku masyarakat, tingkah laku individu dalam masyarakat,

24 Hery Noer Aly (1999), Ilmu Pendidikan Islam (Cet. 1), hlm. 76. 
perubahan kehidupan masyarakat, memperkaya pengalaman masyarakat.

c. Tujuan profesional yang berkaitan dengan pendidikan dan pengajaran sebagai ilmu, sebagai seni, sebagai profesi, dan sebagai kegiatan masyarakat ${ }^{25}$.

\section{Kurikulum Pendidikan Islam}

Kurikulum merupakan salah satu komponen yang sangat menentukan dalam suatu sistem pendidikan, karena kurikulum merupakan alat untuk mencapai tujuan pendidikan dan sekaligus sebagai pedoman dalam pelaksanaan pengajaran pada semua jenis dan tingkat pendidikan.

Tujuan pendidikan di suatu bangsa atau negara ditentukan oleh falsafah dan pandangan hidup bangsa atau negara tersebut. Berbedanya falsafah dan pandangan hidup suatu bangsa atau negera menyebabkan berbeda pula tujuan yang hendak dicapai dalam pendidikan tersebut. Begitu pula perubahan politik pemerintahan suatu negara mempengaruhi pula bidang pendidikan, yang sering membawa akibat terjadinya perubahan kurikulum yang berlaku. Oleh karena itu, kurikulum bersifat dinamis guna lebih menyesuaikan dengan berbagai perkembangan yang terjadi ${ }^{26}$.

Kurikulum pendidikan Islam adalah rencana pendidikan yang memberi pedoman tentang jenis, lingkup, dan urutan isi, serta proses pendidikan.

Prinsip-prinsip kurikulum pendidikan Islam dibangun atas dasar pemikiran yang Islami dengan Al-Qur'an dan Al-Hadits serta ijma' para ulama sebagai landasan uatamanya, dengan mengabungkan halhal baru yang ngandung unsur positif dan benar, seperti kaidah dibawah ini:

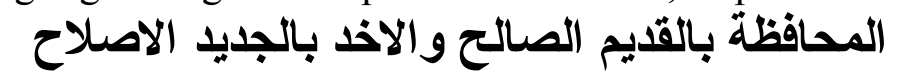

25 Omar Muhammad Al-Toumy Al-Syaibany, Falsafatut Tarbiyah Islamiyah, hlm. 478. 26 Ibid., hlm. 476. 
"mempertahankan hal-hal lama yang baik dan mengambil halhal baru yang lebih baik"

\section{Kajian Tentang Nilai- Nilai Pendidikan Islam}

Setelah uraian nilai dan pendidikan Islam dipaparkan pada pembicaraan terdahulu, selanjutnya akan kami paparkan tentang nilai-nilai pendidikan Islam, yang mana nilai-nilai Pendidikan Islam ini adalah harapan tentang sesuatu/sifat-sifat/hal-hal yang berguna dan bermanfaat bagi manusia dan diugemi sebagai acuan tingkah laku yang melekat pada pendidikan Islam yang digunakan sebagai dasar manusia untuk mencapai tujuan hidupnya yaitu mengabdi pada Allah SWT supaya bahagia di dunia dan di akhirat.

Nilai-nilai Pendidikan Islam sesungguhnya terkait erat dengan nilai-nilai yang ada dalam Islam itu sendiri. Dimana nilainilai yang ada dalam islam itu berusaha ditransformasikan kepada umat islam melalui pendidikan Islam. Nilai-nilai Islam yang ditransformasikan melalui pendidikan Islam ini kemudian terlembagakan menjadi nilai-nilai Pendidikan islam. ${ }^{27}$

Nilai-nilai Islam yang terlembagakan menjadi nilai-nilai Pendidikan Islam jumlahnya banyak sekali namun pada konsepnya dapat tergolong menjadi empat bagian, hal ini kami merujuk pada sebuah skripsi karangan Triwidyastuti. Mahasiswi Fakultas Tarbiyah UIN Sunan Kalijaga Yogyakarta, dengan judul Nilainilai Pendidikan Islam dalam Hadits Perintah Sholat Bagi Anak (H.R.Imam Abu Daud). Yakni sebagai berikut :

\section{$\begin{array}{llll}\text { A. Nilai-nilai } & \text { pendidikan } & \text { Islam }\end{array}$ Keimanan/kepercayaan (agama).}

27 Prof. Dr. Hj. Siti Muri'ah, 2011, Nilai-Nilai Pendidikan Islam dan Wanita karir, Rasail media group, Semarang, hlm. 11. 
Iman adalah kepercayaan yang terhujam kedalam hati dengan penuh keyakinan, tak ada perasaan syak (ragu-ragu) serta mempengaruhi orientasi kehidupan, sikap dan aktivitas keseharian. ${ }^{191}$

Al-Ghazali mengatakan iman adalah mengucapkan dengan lidah, mengakui benarnya dengan hati dan mengamalkan dengan anggota badan. ${ }^{192}$

Pembentukan iman harus diberikan pada anak sejak kecil, sejalan dengan pertumbuhan kepribadiannya. Nilai-nilai keimanan harus mulai diperkenalkan dengan cara :

a. Memperkenalkan nama Allah SWT dan Rasul-Nya

b. Memberikan gambaran tentang siapa pencipta alam raya ini melalui kisah-kisah teladan

c. Memperkenalkan ke-Maha-Agungan Allah SWT. ${ }^{193}$

Rasulullah SAW. Adalah orang yang menjadi suri tauladan (Uswatun Hasanah) bagi umatnya, baik sebagai pemimpin maupun orang tua. Beliau mengajarkan pada umatnya bagaimana menanamkan nilai-nilai keimanan. Ada lima pola dasar

\footnotetext{
191

Yusuf Qardawi, 2000, Merasakan kehadiran Tuhan, Mitra Pustaka, Yogyakarta. hlm. 27 192

Zainudin, et., al 1991, Seluk Beluk Pendidikan dari Al-Ghazali, Bina Aksara, Jakarta, hlm. 97193

M. Nippan Abdul Halim, Anak Sholeh Dambaan Keluarga, Cet II, Mitra Pustaka, Yogyakarta, hlm.176

pembinaan iman (Aqidah) yang harus diberikan pada anak usia dini, yaitu membacakan kalimat tauhid pada anak, menanamkan kecintaan
} 
kepada Allah SWT dan Rasul-Nya, mengajarkan ALQur'an dan menanamkan nilai-nilai perjuangan dan pengorbanan. ${ }^{28}$

Nilai-nilai keimanan yang diberikan sejak anak masih kecil, dapat mengenalkannya pada Tuhannya, bagaimana ia bersikap pada Tuhannya dan apa yang mesti diperbuat di dunia ini.

\section{B. Nilai-nilai Pendidikan Islam Tentang Kesehatan.}

Kesehatan adalah masalah penting dalam kehidupan manusia, terkadang kesehatan dipandang sebagai sesuatu yang biasa dalam dirinya. Orang baru sadar akan pentingnya kesehatan bila suatu saat dirinya atau keluarganya jatuh sakit. Dengan kata lain arti kesehatan bukan hanya terbatas pada pokok persoalan sakit kemudian di cari obatnya.

Kesehatan dibutuhkan setiap orang, apalagi orang-orang islam. Dengan kesehatan aktifitas keagamaan dan dunia dapat dikerjakan dengan baik. Orang bekerja butuh tubuh yang sehat, begitu juga dalam melaksanakan ibadah pada Allah SWT semua aktifitas di dunia memerlukan kesehatan jasmani maupun rohani.

Mengingat pentingnya kesehatan bagi umat islam apalagi dalam era modern seperti sekarang ini banyak sekali penyakit baru yang bermunculan. Maka perlu kiranya bagi orang tua muslim untuk lebih memperhatikan anak-anaknya dengan memasukkan pendidikan islam tentang kesehatan sebagai unsur pokok. ${ }^{29}$

Usaha penanaman kebiasaan hidup sehat bisa dilakukan dengan car mengajak seseorang agar gemar berolah raga terutama pada anak-anak usia dini, serta memberikan keteladanan dalam

28 M. Nur Abdul Hafizh, "Manhaj Tarbiyah Al-Nabawiyah Li Al-Thif". Penerj. Kuswandini, 1997, Mendidik Anak Bersama Rasulullah, cet I, Al-Bayan, Bandung, hlm. 110.

29 M. Nippan Abdul Halim, Op. Cit., hlm. 119 
menjaga kebersihan diri dan lingkungan dan memberikan pengetahuan secukupnya tentang pentingnya kebersihan. ${ }^{30}$

Jadi, dengan demikian Pendidikan Islam menganjurkan pada orang tua menjaga kesehatan dimulai sejak dini atau anak masih bayi, karena membiasakan hidup bersih dan sehat dapat dibiasakan sejak kecil.

\section{Nilai-nilai pendidikan Islam tentang Ibadah.}

Ibadah semacam kepatuhan dan sampai batas penghabisan, yang bergerak dari perasaan hati untuk mengagungkan kepada yang disembah. Kepatuhan yang dimaksud adalah seorang hamba yang mengabdikan diri pada Allah SWT.

Ibadah merupakan bukti nyata bagi seorang muslim dalam meyakini dan mempedomani aqidah Islamiyah. Sejak dini seseorang harus diperkenalkan dengan nilai-nilai ibadah dengan cara:

a. Mengajak anak ke tempat ibadah

b. Memperkenalkan bentuk-bentuk ibadah

c. Memperkenalkan arti ibadah. ${ }^{31}$

\section{Kajian Tentang Perayaan Peringatan Maulid Nabi}

Muhammad SAW

\section{Pengertian Maulid Nabi Muhammad SAW}

Kata Maulid, dalam bahasa Arab, merupakan isim zaman/makan (kata yang menunjukkan arti waktu/tempat) dari

30 lbid., hlm. 192

31 lbid., hlm. 179. 
tashrif/kata walada-yulidu. Jika walada berarti lahir, maka maulid berarti waktu kelahiran / tempat kelahiran. ${ }^{32}$

Maulid Nabi Muhammad SAW kadang-kadang Maulid Nabi atau Maulud saja (bahasa Arab: مولد النبي, mawlid annabî), adalah peringatan hari lahir Nabi Muhammad SAW, yang di Indonesia perayaannya jatuh pada setiap tanggal 12 Rabiul Awal dalam penanggalan Hijriyah. Kata maulid atau milad dalam bahasa Arab berarti hari lahir. ${ }^{33}$

Perayaan Maulid Nabi merupakan tradisi yang berkembang di masyarakat Islam jauh setelah Nabi Muhammad SAW wafat. Secara subtansi, peringatan ini adalah ekspresi kegembiraan dan penghormatan kepada Rasulullah Muhammad SAW. ${ }^{34}$

\section{Sejarah Peringatan Hari Maulid Nabi}

Perayaan maulid nabi dalam sejarah islam sudah berlangsung lama, sejak ribuan tahun yang lalu. Setidaknya ada tiga teori yang yang menjelaskan tentang asal mula perayaan peringatan maulid Nabi.

Pertama, perayaan maulid pertama kali di adakan oleh kalangan dinasti Ubaid (Fathimi) di mesir yang berhaluan Syiah Islamiyah (Rafidhah). Mereka berkuasa di mesir tahun $362-567$ Hijriyah, atau sekitar abad 4-6 Hijriyah. Mula-mula dirayakan di era kepemimpinan Abu Tamim yang bergelar, Al- Mu'iz $\mathrm{Li}$ Dinillah.

Kedua,perayan maulid di kalangan Ahlus Sunnah, bahkan menurut imam Jalaluddin As-Suyuti termasuk imam ahli hadist dan sejarah yang paling giat mendukung peryaan maulid Nabi

32 http://belajarnu.blogspot.com/2013/01/pengertian-maulid-nabi.html

33 http://id.wikipedia.org/wiki/Maulid_Nabi_Muhammad

34 http://oleander0.blogspot.com/2013/02/makalah-maulid-nabi-muhammadsaw_20.html 
Muhammad, beliau menjelaskan bahwa orang pertama kali merintis peringatan maulid Nabi adalah Sultan Abu Said Muzhaffar Kukabri bin Zinuddin bin Baktatin, gubernur irbil wilayah irak. Beliau hidup pada tahun 549-630 H.

Ketiga,perayaan maulidpertama kali di adakan oleh Sultan Shalahuddin Al Ayyubi (567-622 H), penguasa Dinasti Ayyub (di bawah kekuasaan daulah Abbassiyah). Tujuan beliau untuk meningkatkan semangat jihad kaum muslimin, dalam rangka menghadapi perang salib melawan kaum salibis dari eropa dan merebut Yerusalem dari tangan kerajaan salibis. ${ }^{35}$

Namun ada juga yang berpendapat lain,salah satunya adalah Sayyid Muhammad Bin Alwi Al Maliki Al Hasani. Beliau menjelaskan dalam bukunya yang berjudul "Wajibkah Memperingati Maulid Nabi SAW ? " jika sesungguhnya yang pertama kali merayakan atau memperingati maulid itu adalah nabi Muhammad SAW sendiri, hal ini berdasar sebuah hadist:

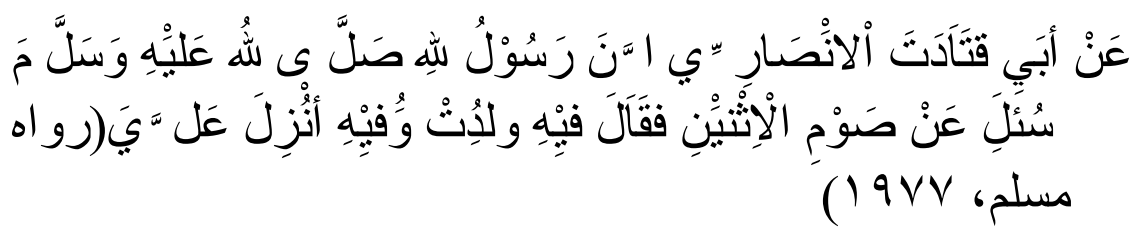

Artinya: "Diriwayatkan dari Abu Qatadah al-Anshari RA bahwa Rasululloh pernah ditanya tentang puasa senin, maka beliau menjawab:" Pada hari itulah aku dilahirkan dan wahyu diturunkan kepadaku."(HR.Muslim:1977)

\section{Awal Maulid Nabi Muhammad SAW berkembang di Indonesia.}

35 AM. Waskito, pro dan kontra Maulid Nabi , hln:23 
Dalam sejarah penyebaran Islam di Nusantara, perayaan Maulid Nabi atau Muludan sudah dilakukan oleh Wali Songo untuk sarana dakwah dengan berbagai kegiatan yang menarik masyarakat agar mengucapkan syahadatain sebagai pertanda memeluk Islam. Itulah sebabnya perayaan Maulid Nabi disebut Perayaan Syahadatain, yang oleh lidah Jawa diucapkan Sekaten

Pada zaman kesultanan Mataram, perayaan Maulid Nabi Muhammad SAW disebut "Gerebeg Mulud". Kata "gerebeg" artinya mengikuti, yaitu mengikuti sultan dan para pembesar keluar dari keraton menuju masjid untuk mengikuti perayaan Maulid Nabi Muhammad SAW, lengkap dengan sarana upacara, seperti nasi gunungan dan sebagainya. Di samping Gerebeg Mulud, ada juga perayaan Gerebeg Poso (menyambut Idul Fitri) dan Gerebeg Besar (menyambut Idul Adha). ${ }^{36}$

\section{Praktik Perayaan Maulid di Masyarakat}

Tiga fakta yang tidak terbantahkan seputar peringatan maulid Nabi, yaitu: (1) Peringatan maulid sudah dilaksanakan sejak lama, berabad-abad yang lalu; (2) Peringatan maulid dilaksanakan oleh kaum muslimin hampir di semua negaranegara muslim; (3) Tata cara dan pelaksanaan peringatanmaulid berbedabedaantara satu tempat dengan yang lain.

Dibawah ini adalah model-model perayaan maulid nabi ditengah masyarakat kita;

a. Peringatan maulid Nabi yang paling ringan, kaum muslimin mengetahui bahwa suatu hari adalah tanggal 12 Rabi'ul

$36 \mathrm{http}: / /$ muda.kompasiana.com/2014/01/14/asal-muasal-maulid-nabi-muhammadsawberkembang-di-indonesia-624377.html 
awal. Di negeri kita mulid nabi termasuk jenis peringatan keagamaan, sehingga di nyatakan sebagai hari libur.

b. Peringatan yang dilakukan di masjid-masjid, kantorkantor, sekolah-sekolah dengan mengadakan ceramah keislaman, lomba-lomba untuk anak muslim, pameran buku, bazar produk muslim, bakti sosial, dan sebagainya.

c. Disebagian pesantren, majlis taklim, organisasi islam, atau masjid-masjid tertentu dengan memdatangkan kyai, habib, serta ustad yang di tokohkan di tempat tertentu dengan rangkaian acara; membaca al qu'an, dzikir-dzikir, pembacaan shalawat nabi, serta manaqib Rasulullah.

d. Peringatan yang di laksanakan secra tradisional oleh komunitas-komunitas kepercayaan, seprti kraton yogya, kraton solo, kraton cirebon setiap tahun merayakan maulid dengan tata cara kental bernuansa kebudayaan. Seperti istilah sekaten dalam kraton yogya dan grebeg mulud dalam kraton solo.

e. Acara maulid yang lebih modern, biasanya diisi dengan kegiatan-kegiatan ilmiah seperti; seminar, simposium, bedah buku dan semacamnya.

\section{E. NILAI-NILAI PENDIDIKAN ISLAM DALAM PERAYAAN PERINGATAN MAULID NABI MUHAMMAD SAW}

Secara umum, ada banyak sekali nilai- nilai atau sesuatu yang berharga pada pribadi dan kehidupan nabi Muhammad SAW, mengingat beliau adalah insan yang sangat komplek, dalam bidang politik, perekonomian, perjuangan serta kepribadian dan akhlaq, 
tidak ada satupun insan yang mampu menyamainya. Kelahiran dan terutusnya beliau adalah rahmat bagi alam semesta.

Allah berfirman :

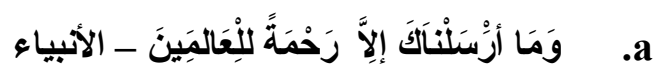

Dan tiadalah Kami mengutus kamu, melainkan untuk (menjadi) rahmat bagi semesta alam. (QS. Al-Anbiya' 107).

Adapun nilai-nilai pendidikan Islam dalam perayaan peringatan maulid Nabi Muhammad SAW adalah sesuatu yang berguna dan bermanfaat. Selain sebagai ekspresi rasa syukur atas kelahiran Rasulullah SAW., substansi dari peringatan Maulid Nabi adalah mengukuhkan komitmen loyalitas pada beliau. Setidaknya, ini terwujud dengan tiga hal.sebagai berikut:

Pertama, meneguhkan kembali kecintaan kepada Rasulullah SAW. Bagi seorang mukmin, kecintaan terhadap Rasulullah SAW. adalah sebuah keniscayaan, sebagai konsekuensi dari keimanan. Kecintaan pada utusan Allah ini harus berada di atas segalanya, melebihi kecintaan pada anak dan isteri, kecintaan terhadap harta, kedudukannya, bahkan kecintaannya terhadap dirinya sendiri. Rasulullah bersabda,

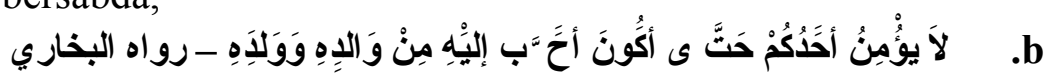

Artinya: Tidaklah sempurna iman salah seorang dari kalian hingga aku lebih dicintainya daripada orangtua dan anaknya. (HR. Bukhari).

Kedua, meneladani perilaku dan perbuatan mulia Rasulullah SAW. dalam setiap gerak kehidupan kita. Allah SWT. bersabda :

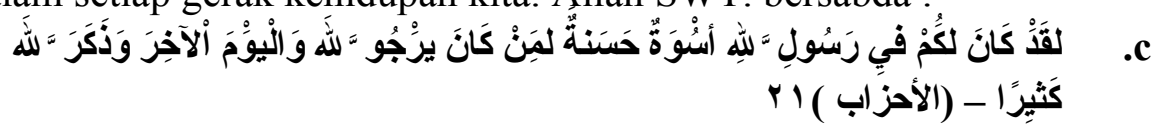


Artinya: Sesungguhnya telah ada pada (diri) Rasulullah itu suri teladan yang baik bagimu (yaitu) bagi orang yang mengharap (rahmat) Allah dan (kedatangan) hari kiamat dan dia banyak menyebut Allah. (QS. Al-Ahzab: 21)

Kita tanamkan keteladanan Rasul ini dalam keseharian kita, mulai hal terkecil, hingga paling besar, mulai kehidupan duniawi, hingga urusan akhirat. Dengan mencontoh sifat-sifat nabi yaitu:

1) Siddiq

Siddiq artinya jujur dan sangat tidak mungkin Rasulullah bersifat bohong (kidzib) Rasulullah sangat jujur baik dalam pekerjaan maupun perkataannya. Apa yang dikatakan dan disampaikan serta yang diperbuat adalah benar dan tidak bohong. Karena akhlak Rasulullah adalah cerminan dari perintah Allah SWT.

2) Amanah

Amanah artinya dapat dipercaya. Sangat tidak mungkin Rasulullah bersifat Khianat atau tidak dapat dipercaya. Rasulullah tidak berbuat yang melanggar aturan Allah SWT. Rasulullah taat kepada Allah SWT. Dan dalam membawakan risalah sesuai dengan petunjuk Allah SWT tidak mengadakan penghianatan terhadap Allah SWT maupun kepada umatnya.

3) Tabligh

Tabligh artinya menyampaikan. Rasulullah sangat tidak mungkin untuk menyembunyikan (kitman). Setiap wahyu dari Allah disampaikan kepada umatnya tidak ada yang ditutup- tutupi atau disembunyikan walaupun yang disampaikan itu pahit dan bertentangan dengan tradisi orang kafir. Rasulullah menyampaikan risalah secara sempurna sesuai dengan perintah Allah SWT. 


\section{4) Fathonah}

Fathonah artinya cerdas. Sangat tidak mungkin Rasul bersifat baladah atau bodoh. Para Rasul semuanya cerdas sehingga dapat menyampaikan wahyu yang telah diterima dari Allah SWT. Rasul adalah manusia pilihan Allah SWT maka sangat tidak mungkin Rasul itu bodoh. Apabila bodoh bagaimana bisa menyampaikan wahyu Allah. ${ }^{37}$

Ketiga, melestarikan ajaran dan misi perjuangan Rasulullah, dan juga para Nabi. Sesaat sebelum menghembuskan nafas terakhir, Rasul meninggalkan pesan pada umat yang amat dicintainya ini. Beliau bersabda:

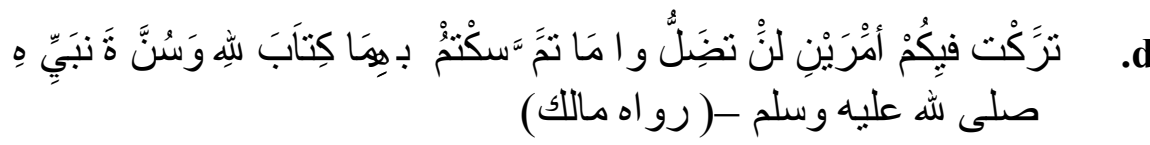

Artinya "Aku tinggalkan pada kalian dua hal, kalian tidak akan tersesat dengannya, yakni Kitabullah dan sunnah NabiNya sallallahu alaihi wa sallam" (HR. Malik).

Bukti kecintaan pada Nabi Muhammad SAW juga akan mendorong umat islam untuk mengerjakan lampahan-lampahan beliau, hal sesuai dengan hadist:

e

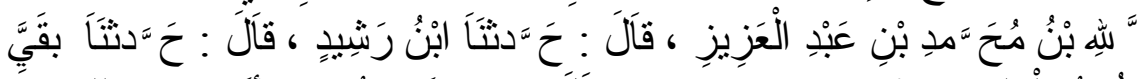

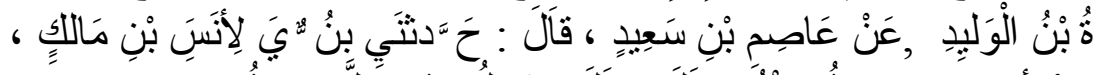

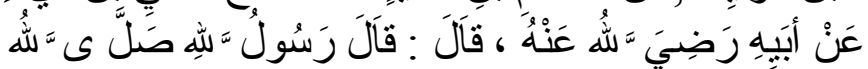

37 http://azizmunawar19.wordpress.com/tag/ringkasan-sejarah-nabi-muhammad-saw/ 


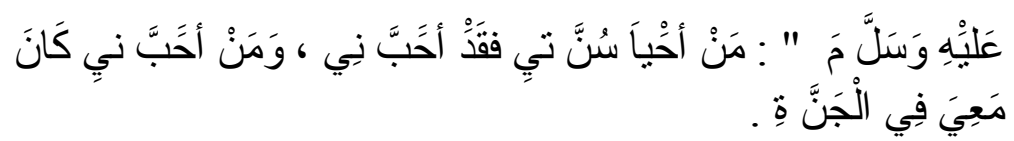

Artinya: dikabarkan oleh Abu Muhammad Abdullah bin Ahmed bin Mahzd Asbahani, ia berkata: berkata Abdullah bin Mohammed Tna bin Abdul Aziz, ia berkata: Ibn Rashid berkata pada kita, ia berkata: Berkata pada kita kami baqiyah Bin al walid, Dari Asim bin Said, ia berkata: anakku berkata padaku pada Anas ibn Malik, dari ayahnya, semoga Allah senang dengan dia, ia berkata: Rasulullah, sawbersabda; Barang Siapa yang menghidupkan kembali sunnahku maka dia sungguh mencintaiku, dan orang yang mencintaiku maka dia akan bersamaku di surga. ${ }^{38}$

Serta meniru $\mathrm{R}$ asulullah SAW selalu menggunakan sistem dan metode dakwah dan pendidikan yang khas dan berbeda dengan kebanyakan sistem dan metode yang digunakan oleh tokoh-t okoh agama lain yang mendahuluinya.y aitu sistem dan metode $d$ idasarkan pada sistem dan metode dakwah Al-Qur'an. Konsep d akwah (دعوة ) dimaksudkan sebagai upaya menyeru dan mengajak orang untuk memeluk Islam; sedangkan konsep pendidikan (نربية (رع) atau تـأديب dimaksudkan untuk memberikan p engertian, pemahaman dan kesadaran yang lebih baik tentang ajaran dan nilainilai ajaran Islam kepada umatnya. ${ }^{39}$

Kedua sistem dan metode ini didasarkan pada firman Allah SWT:

38 http://library.islamweb.net/hadith/display_hbook.php?hflag=1\&bk_no=1552\&pid=8962 47

39 https://m.facebook.com/notes/kh-irfan-hielmy/setetes-hikmah-peringatan-kelahirannabimuhammad-saw/10150355062070063/ 


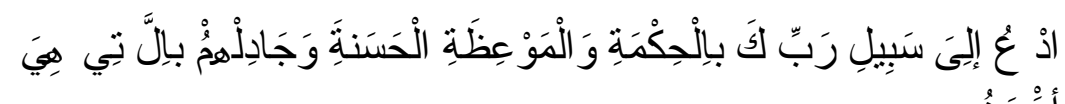

Artinya: serulah (manusia) kepada jalan Tuhan-mu dengan hikmah dan pelajaran yang baik dan bantahlah mereka dengan cara yang baik.

Ada juga yang berpedapat bahwa Tujuan dari perayaan maulidurrosul adalah untuk mengembalikan semangat juang kaum muslimin dalam perjuangan membebaskan Masjid al-Aqsha di Palestina dari cengkraman kaum Salibis. Yang kemudian, menghasilkan efek besar berupa semangat jihad umat Islam menggelora pada saat itu. Secara subtansial, perayaan Maulid Nabi adalah sebagai bentuk upaya untuk mengenal akan keteladanan Nabi Muhammad SAW sebagai pembawa ajaran agama Islam. Tercatat dalam sepanjang sejarah kehidupan, bahwa Nabi Muhammad SAW adalah pemimipn besar yang sangat luar biasa dalam memberikan teladan agung bagi umatnya.

Dalam konteks ini, Maulid harus diartikulasikan sebagai salah satu upaya transformasi diri atas kesalehan umat. Yakni, sebagai semangat baru untuk membangun nilai-nilai profetik agar tercipta masyarakat madani (Civil Society) yang merupakan bagian dari demokrasi seperti toleransi, transparansi, anti kekerasan, kesetaraan gender, cinta lingkungan, pluralisme, keadilan sosial, ruang bebas partisipasi, dan humanisme. Dalam tatanan sejarah sosio antropologis Islam, Nabi Muhammad SAW dapat dilihat dan dipahami dalam dua dimensi sosial yang berbeda dan saling melengkapi.

Pertama, dalam perspektif teologis-religius, Nabi Muhammad SAW dilihat dan dipahami sebagai sosok nabi sekaligus rasul terakhir dalam tatanan konsep keislaman. Hal ini memposisikan Nabi Muhammad SAW sebagai sosok manusia sakral yang merupakan 
wakil Tuhan di dunia yang bertugas membawa, menyampaikan, serta mengaplikasikan segala bentuk pesan "suci" Tuhan kepada umat manusia secara universal.

Kedua, dalam perspektif sosial-politik, Beliau dilihat dan dipahami sebagai sosok politikus andal. Sosok individu Nabi Muhammad SAW yang identik dengan sosok pemimpin yang adil, egaliter, toleran, humanis, serta non-diskriminatif dan hegemonik, yang kemudian mampu membawa tatanan masyarakat sosial Arab kala itu menuju suatu tatanan masyarakat sosial yang sejahtera dan tentram ${ }^{40}$.

Dalam perkembangan selanjutnya, perayaan maulid Nabi makin beragam corak dan warnanya, sesuai dengan perkembangan adat, tradisi, kondisi sosio-kultural masyarakat. Di Lombok umpamanya perayaan Maulid Nabi kental dengan tradisi praja, nyunatan, ngurisan dan beberapa tradisi lainnya. Jika dianalisa, perayaan Maulid Nabi di Pulau Lombok termotivasi 3 faktor: pertama: motivasi historis, secara historis umat Islam meyakini sepenuhnya legalitas Muhammad sebagai sosok figur yang berjasa membangun sebuah peradaban baru dengan melakukan sebuah reformasi yang fundamental terhadap tradisi jahiliyah yang ketika itu berada pada degradasi moral yang sangat memprihatinkan. Dalam kondisi tersebut, Muhammad selanjutnya bangkit dengan memformulasikan sebuah tatanan kehidupan yang etis dan egalitarian yang dibingkai dalam figura al Quran dan al Hadits. Dengan demikian, 12 Rabiul Awal merupakan tonggak sejarah yang memotivasi masyarakat untuk merayakan maulid Nabi sebagai bentuk ungkapan rasa syukur atas kehadiran beliau di tengah-tengah masyarakat dunia.

40 http://ppp.or.id/news/makna-dan-hikmah-maulid-nabi-muhammad-saw.html 
Situasi dan kondisi umat yang semakin terpuruk akibat kontak budaya dan peradaban yang 'menggila', juga turut mengundang motivasi masyarakat untuk merayakan kelahiran Nabi sebagaimana yang telah dilakukan sebelumnya oleh Shalahuddin al Ayyubi pada abad ke XII.

Kedua: motivasi teologis, aspek teologis ternyata juga memiliki peran yang cukup strategis dalam memotivasi masyarakat merayakan maulid Nabi. Hal ini dapat dilihat dari fatwa-fatwa yang dikemukakan oleh para ulama madzhab Hanafi dan Maliki yang mengemukakan bahwa "diktum hukum yang ditetapkan dengan diktum tradisi sama dengan diktum hukum yang ditetapkan berdasarkan hukum syar'i". Hal yang senada pernah juga diungkapkan oleh Syarakhsyi yang menyebutkan bahwa "menetapkan hukum dengan tradisi seolah-olah menetapkan hukum dengan nash". Namun hukum yang ditetapkan berdasarkan tradisi tersebut sejatinya harus memiliki relevansi dan senafas dengan nilai-nilai al Quran dan al Hadits.

Ketiga: motivasi filosofis-sosiologis, masyarakat merupakan sebuah sistem yang terdiri dari kumpulan sekian banyak individu kecil maupun besar yang terikat oleh satuan adat, tradisi, hukum dan hidup bersama. Masyarakat akan dapat hidup tegak berdiri jika instrumen dalam masyarakat tersebut dapat berinteraksi dengan harmonis, tanpa adanya ketimpangan-ketimpangan sosial yang dapat menyuburkan benih-benih pertikaian. Dengan demikian, secara filosofis-sosiologis, perayaan maulid Nabi dapat dijadikan sebagai suplemen yang akan menggugah semangat serta sebagai pondasi yang akan memperkokoh bangunan ukhuwah masyarakat yang diwujudkan dalam sebuah kebersamaan. ${ }^{41}$ DAFTAR PUSTAKA

Al-Qur'an dan Terjemahnya, Surat Al-Mujadalah:11

Abdul Aziz, Zainuddin ibn. Irsyadu Al Ibat

41 http://an-nady.blogspot.com/2013/02/refleksi-atas-peringatan-maulid-nabi.html 
Al-Ghamawi, Muhammad Zuhri (1995). Al-Siraj Al-Wahhaj. Dzar Alfikr, Bairut.

Ahmadi, Abu dan Noor Salimi. (2004). Dasar-Dasar Pendidikan Islam, Bumi Aksara, Jakarta.

Al-Jauhari, Hamri. Fiqhi untuk Madrasah Tsanawiyah Kelas VIII. Bintang Ilmu, Surabaya.

Al-Qardhawi, Yusuf. (1980). Pendidikan Islam dan Madrasah Hasan Al-Banna. (terj. Bustami A, Gani et.al). Bulan Bintang, Jakarta.

Arifin, Muzayyin, H. (2003). Filsafat Pendidikan Islam. PT. Bumi Aksara, Jakarta.

Jakarta.

(1991). Ilmu Penddidikan Islam. Bumi Aksara,

Aris, Djauhari. Fiqh Islam. Al-Ikhsan, Surabaya. Miftahul Ushul. Al-Ikhsan, Surabaya.

Al-Toumy Al-Syaibany, Omar Muhammad. Falsafatut Tarbiyah Islamiyah. (terj. Hasan Langgulung). Bulan Bintang, Jakarta.

Baharuddin dan Esa Nur Wahyuni. (2007). Teori Belajar dan Pembelajaran. Ar-ruzz Media, Yogjakarta.

Djumransjah. (2006). Filsafat Pendidikan Islam. Bayu Media, Malang.

Departemen Kementrian Agama RI. (2012). Tuntunan Praktis Manasik Haji dan Umrah. Kemenag, Jakarta. 
Departemen Pendidikan Nasional. (2011). Kamus besar Bahasa Indonesia Pusat Bahasa. PT. Garamedia Pustaka Utama, Jakarta. (2003). Undang-undang

Republik Indonesia tentang Sistem Pendidikan Nasional. (SISDIKNAS).

D. Marimba, Ahmad. (1989). Pengantar Filsafat Pendidikan Islam. Al Ma'arif , Bandung.

Gazalba, Sidi. (1981). Sistematika Filsafat Buku IV. Bulan Bintang, Jakarta.

Hasbullah. (2001). Dasar-dasar Ilmu Pendidikan. PT. Raja Grafindo Persada, Jakarta.

HMI Cab. Bogor. (1989). Nilai-Nilai Identitas Kader NIK. Buku Pedoman HMI Cab, Bogor.

http://paksalam.wordpress.com/2009/05/02/sembilan-aspekpendidikan$\underline{\text { Islam/ }}$

Ikhsan, Mohammad. (2009). Dalam (http://www.mohammadikhsan19.co.cc/2009/09/nilainilaipendidikan-dalam-haji.html).

Langgulung, Hasan. (1980). Beberapa Pemikiran tentang Pendidikan Islam. Al-Ma'arif, Bandung.

Nata, Abuddin, H. (2004). Metodologi Studi Islam. (Cet. 9). PT. Raja Grafindo Persada, Jakarta.

Noer Aly, Hery. (1999). Ilmu Pendidikan Islam. (Cet. 1). PT. Logos, 
Jakarta.

Qosim, Ibnu. Fathu Al-Qorib Al-Mujib. Nur Al-Huda, Surabaya.

Saifuddin, Endang. (1982). Agama Dan Kebudayaan. Bina Ilmu, Surabaya.

Shanty. (2011). Pentingnya Pendidikan, dalam (http://researchengines.com/0607shanty.html)

Suwarno, Wiji. (2006). Dasar-dasar Ilmu Pendidikan. Ar-ruzz Media, Jogjakarta.

Taqiyuddin. Kifayah Al-Akhyar. juz I. Nur Al-Huda, Surabaya.

Tholchah Hasan, Muchammad. (1986). Prospek Islam dalam Menghadapi Tantangan Zaman. Bangun Prakarya, Jakarta.

Yunus, H. A., Drs. S.H. (1999). Filsafat Pendidikan. CV. Citra Sarana Grafika, Bandung.

Zainuddin. Qurrotu Al-Aini. Nur Al-Huda, Surabaya. 
